Originalartikkel

\title{
Legemiddelshopping av vanedannende medikamenter i Norge
}

\begin{abstract}
Sammendrag
Bakgrunn. Fastlegeordningen skulle blant annet begrense mulighetene for å gå fra lege til lege for å få vanedannende legemidler, såkalt legemiddelshopping.
\end{abstract}

\begin{abstract}
Materiale og metode. Data fra Reseptregisteret for 2004 ble analysert med henblikk på hvor mange leger enkeltpasienter har benyttet for å få forskrevet ett og samme legemiddel, samt sammenhengene mellom antall leger benyttet, utlevert mengde av legemidlet og samtidig totalforbruk av benzodiazepiner og opioider. Utleveringsmønstrene for tre potensielt vanedannende legemidler (diazepam, karisoprodol og kodeinkombinasjoner) ble sammenliknet med tre legemidler som ikke regnes som vanedannende (esomeprazol, metformin og salbutamol).
\end{abstract}

Resultater. Over $96 \%$ av brukerne benyttet kun én eller to leger uansett legemiddel, og under $0,5 \%$ benyttet fem eller flere. For de vanedannende legemidlene var andelen av brukerne som benyttet fem eller flere leger 9,5 ganger større enn for de ikke-vanedannende legemidlene. Både utlevert mengde av aktuelt legemiddel og samtidig utlevert totalmengde benzodiazepiner og opioider økte med antall leger benyttet, mer for de vanedannende enn for de ikke-vanedannende legemidlene.

Fortolkning. Omfanget av legemiddelshopping er begrenset. Av fåtallet som benyttet mange leger, var fenomenet langt mer utbredt blant brukere av vanedannende legemidler enn blant brukere av ikke-vanedannende legemidler. Legemiddelshopping kan være tegn på et legemiddels misbrukspotensial.

\author{
Rolf B. Winther \\ rbw@fmbu.no \\ Fylkesmannen i Buskerud \\ Postboks 1604 \\ 3007 Drammen
}

\section{Jørgen G. Bramness*}

Avdeling for legemiddelepidemiologi

Nasjonalt folkehelseinstitutt

* Nåværende adresse:

Senter for rus og avhengighetsforskning

Universitetet i Oslo

Forbruket av potensielt vanedannende legemidler i Norge øker (1). Bruk av slike legemidler innebærer fare for avhengighet, misbruk og rusproblemer (2). Det er sammenheng mellom bruk av legalt forskrevne vanedannende legemidler og overdosedødsfall blant rusmiddelmisbrukere $(3,4)$. Noen pasienter får forskrevet mye av slike legemidler fra én lege, mens andre pasienter bevisst går fra lege til lege for å skaffe vanedannende legemidler, enten for eget bruk eller for videresalg til andre (5). Dette fenomenet kalles ofte «legeshopping» $(6,7)$, men vil mer presist i denne artikkelen omtales som «legemiddelshopping». En australsk studie beskriver heroinmisbrukere som i tiden før en fatal overdose viste en økende grad av legemiddelshopping, og som i denne perioden fikk forskrevet betydelige mengder vanedannende legemidler, særlig benzodiazepiner og opioidanalgetika (4).

At en pasient får legemidler fra flere leger, kan skyldes ordinært bytte av fastlege, at fastlegen har vikar, at pasienten eller legen flytter, eller behandling hos spesialist. Pasienten kan også tenkes å søke annen lege på grunn av akutt sykdom, lang ventetid hos fastlegen, eller fordi pasienten ønsker en vurdering hos annen lege.

Siden fastleger bare unntaksvis skal forskrive legemidler til andre enn egne listepasienter, ble det ved innføringen av fastlegeordningen forutsatt at denne effektivt skulle begrense legemiddelshopping $(8,9)$. I 2004 var det kun $0,5 \%$ av befolkningen som ikke var tilsluttet fastlegeordningen, mens ytterligere 1,6\% var tilsluttet liste uten lege eller ikke hadde plass på liste (10).

Nasjonalt reseptbasert legemiddelregister (Reseptregisteret) ble opprettet med virkning fra 1.1. 2004. Vi ønsket å benytte registeret til å studere omfanget av legemiddelshopping i Norge med henblikk på utvalgte medikamenter. Vi ville dessuten undersøke: Hvor mange leger er det vanlig å benytte for forskrivning av legemidler i løpet av ett kalenderår? Kan antallet leger som benyttes, fortelle oss noe om et legemiddels misbruksfare?

\section{Materiale og metode}

Data ble hentet fra Reseptregisteret, som gir informasjon om alle utleveringer av legemidler fra apotekene i Norge (11). Alle pasienter registreres på grunnlag av sitt fødselsnummer med et brukerpseudonym, kjønn, fødselsår og bostedskommune. Tilsvarende registreres forskriveren på grunnlag av sitt helsepersonellnummer med et rekvirentpseudonym, kjønn, alder, profesjon og spesialitet. Det registreres ikke hvorvidt forskriveren er fastlege. Pseudonymene er unike for hvert individ, slik at den samme pasienten eller den samme legen kan følges over tid uten at den enkelte kan bli identifisert. Reseptregisteret kan derfor ikke brukes til kontroll av enkeltpasienter eller forskrivere. Utlevert legemiddel registreres med blant annet styrke, mengde og utleveringsdato.

Det ble gjort uttrekk av data fra Reseptregisteret for kalenderåret 2004 for utleveringen av tre legemidler med antatt potensial for misbruk (diazepam, karisoprodol og kodeinkombinasjoner). Disse ble sammenliknet med tilsvarende data for tre legemidler man ikke antok hadde et slikt potensial (esomeprazol, metformin og salbutamol). Vi valgte disse seks legemidlene fordi de har et stort salgsvolum, og fordi vi antok at de profilmessig, ut ifra sine virkninger og forskjeller $\mathrm{i}$ attraktivitet blant legemiddelmisbrukere, gjenspeiler ulikheter i utleveringsmønstrene mellom vanedannende og ikkevanedannende legemidler. På grunnlag av forskjeller i utleveringsmønstrene for disse legemidlene, ble omfanget av legemiddelshopping studert. Hovedvariabelen i studien

\section{Hovedbudskap}

- Få pasienter bruker mer enn to leger for å få forskrevet ett og samme legemiddel

- Bruk av mange leger er hyppigere ved vanedannende enn ikke-vanedannende legemidler

- Fastlegeordningen har ikke forhindret at et fåtall pasienter besøker mange leger for å få tak i legemidler med misbrukspotensial 
var antall forskjellige leger som forskrev ett spesifikt medikament til den samme pasienten i løpet av kalenderåret 2004. Mengden utlevert legemiddel ble angitt i definerte døgndoser (DDD) (1) og ble sammenholdt med antall leger benyttet. Brukerne av disse legemidlene ble - kategorisert etter legemiddel og antall leger benyttet - også studert med hensyn til den totale mengden av benzodiazepiner og opioider som den enkelte fikk utlevert i samme tidsperiode. For diazepambrukerne inngikk diazepam i denne totale mengden benzodiazepiner, og for brukerne av kodeinkombinasjoner inngikk kodein tilsvarende i total mengde opioider. Den såkalte Lorenz $1 \%$-verdien ble benyttet for å kvantifisere skjevfordelingen i forbruket av et legemiddel (12). Verdien beskriver andelen av den totale mengde utlevert legemiddel som ble utlevert til den $1 \%$ av pasientene som fikk utlevert mest. Jo høyere Lorenz $1 \%$-verdien er, desto skjevere er fordelingen av forbruket. En skjev fordeling av forbruk kan indikere misbruk.

\section{Resultater}

Tabell 1 viser antall brukere for hvert av de undersøkte legemidlene, totalt og etter antall leger benyttet, samt maksimalt antall leger benyttet av minst én pasient og Lorenz $1 \%$ verdiene. Få pasienter benyttet fem eller flere leger. Men tabellen viser at andelene som gjorde dette, var langt større ved bruk av de vanedannende enn ved bruk av de ikke-vanedannende legemidlene. Gjennomsnittet av andelene for de vanedannende er 9,5 ganger større enn for de ikke-vanedannende. Maksimalt antall leger benyttet var også høyere for de vanedannende legemidlene. Lorenz $1 \%$-verdiene viser større skjevhet $\mathrm{i}$ forbruket for de vanedannende legemidlene enn for de ikke-vanedannende, med unntak for salbutamol.

Figur 1 viser samvariasjonen mellom utlevert mengde av det aktuelle legemidlet og total mengde utlevert av benzodiazepiner og opioider for hvert av de seks legemidlene etter antall leger benyttet for forskrivning av det aktuelle legemidlet. Dette er vist ved fremstilling av 75-prosentilene for disse legemidlene. For alle de seks legemidlene økte utlevert mengde av det aktuelle legemidlet med antall leger pasienten har benyttet, men i hovedsak mer for de vanedannende legemidlene, med unntak av salbutamol. Den samtidig utleverte totalmengden benzodiazepiner og opioider økte også med økende antall leger for de vanedannende, men i hovedsak ikke for de ikke-vanedannende legemidlene. Unntaket var utlevert mengde benzodiazepiner hos salbutamolbrukere som benyttet fem eller flere leger.

Det ble ikke avdekket konsistente forskjeller mellom menn og kvinner med hensyn til legemiddelshopping. Det var likevel gjennomgående at flertallet brukere for alle legemidlene, unntatt metformin, var kvinner (tab 1).

\section{Diskusjon}

Legemiddelshopping var ikke hyppig for medikamentene undersøkt i denne studien. Uavhengig av legemiddel, benyttet de aller fleste personene seg av kun én lege. $2-4 \%$ av pasientene som brukte de vanedannende legemidlene, benyttet mer enn to leger i løpet av ett år for å få forskrevet legemidlet, mens tilsvarende for de ikke-vanedannende kun var 1-1,5\%. For begge legemiddelgruppene var andelen som brukte fem eller flere leger under $1 \%$, men relativt sett langt større for gruppen av vanedannende legemidler. Det maksimale antallet leger benyttet av minst en bruker, var også langt høyere for de vanedannende enn for de ikke-vanedannende legemidlene. De som benyttet mange leger for resepter på vanedannende legemidler, fikk også forskrevet en betydelig større totalmengde av benzodiazepiner og opioider.

At man benytter kun én eller noen få leger for å få forskrevet legemidler, dvs. ikke er legemiddelshopper, er ikke ensbetydende med at man ikke har en problematisk bruk av vanedannende legemidler. Legemiddelshopping vil imidlertid kunne indikere problematisk bruk av disse medikamentene $(4,6)$. Ett av de viktigste funnene i undersøkelsen er at legemidler med kjent misbrukspotensial blir anskaffet ved legemiddelshopping.

Våre funn er ikke direkte sammenliknbare med resultater fra andre undersøkelser. En beskrivelse av omfanget av legemiddelshopping vil avhenge av hvordan man studerer og definerer fenomenet, herunder hvor lang tidsperiode og hvor mange leger pasienten skal ha oppsøkt innenfor denne, for å oppfylle kriteriet for å være en legemiddelshopper (13). I noen undersøkelser har man studert legesøkende atferd generelt $(4,6)$, mens i andre, som i denne undersøkelsen, forskrivning av bestemte medikamenter $(7,14)$. I vår undersøkelse har vi brukt et nasjonalt reseptregister som dekker hele befolkningen for å studere fenomenet, mens andre f.eks. har brukt rettsmedisinske journaler (3) eller registre over offentlig subsidierte forskrivninger og helsetjenester (4).

Alvorligheten av fenomenet legemiddelshopping er større enn det antallet legemiddelshoppere skulle tilsi. Studier viser at forskrivningsmedikamenter og legemiddelshopping er nært knyttet til overdoser og overdosedødsfall, og at samtidig benzodiazepinbruk ofte henger sammen med dette $(3,4,15)$.

Høye verdier for Lorenz 1-prosentilen (tab 1) viser at noen pasienter er storforbrukere av legemidlet, hvilket kan indikere misbruk (12). Dette underbygges av at Lorenz 1-prosentilene samlet sett viser en større skjevfordeling av forbruket blant brukerne

Tabell 1 Antall brukere i 2004 for hvert av de unders $ø$ kte legemidlene, totalt og andel kvinner (angitt i absolutte tall og prosent), og etter antall leger benyttet (prosent), maksimalt antall leger benyttet av minst én pasient, og Lorenz $1 \%$-verdiene. Verdien beskriver andelen av den totale mengde utlevert legemiddel som ble utlevert til den $1 \%$ av pasientene som fikk utlevert mest, slik at jo høyere Lorenz $1 \%$-verdien er, desto skjevere er fordelingen av forbruket

\begin{tabular}{|c|c|c|c|c|c|c|c|c|c|}
\hline & \multirow[b]{2}{*}{ Antall } & \multirow[b]{2}{*}{$(\%)$} & \multicolumn{5}{|c|}{ Antall leger benyttet } & \multirow{2}{*}{$\begin{array}{l}\text { Maksimalt } \\
\text { antall leger }\end{array}$} & \multirow[b]{2}{*}{ Lorenz $1 \%$} \\
\hline & & & 1 & 2 & 3 & 4 & $\geq 5$ & & \\
\hline Diazepam & 150156 & $(100)$ & 85,6 & 11,8 & 2,1 & 0,5 & 0,12 & 11 & 10,6 \\
\hline - kvinner & 97212 & (65) & & & & & & & \\
\hline Karisoprodol & 84319 & $(100)$ & 88,7 & 9,1 & 1,6 & 0,4 & 0,19 & 25 & 17,7 \\
\hline - kvinner & 54178 & (64) & & & & & & & \\
\hline Kodeinkombinasjoner & 378524 & (100) & 82,8 & 13,5 & 2,8 & 0,6 & 0,26 & 17 & 16,4 \\
\hline - kvinner & 214070 & (57) & & & & & & & \\
\hline Esomeprazol & 112138 & $(100)$ & 87,9 & 10,7 & 1,2 & 0,2 & 0,02 & 8 & 5,3 \\
\hline - kvinner & 60052 & (54) & & & & & & & \\
\hline Metformin & 59536 & $(100)$ & 89,1 & 9,5 & 1,2 & 0,2 & 0,03 & 6 & 3,2 \\
\hline - kvinner & 28672 & (48) & & & & & & & \\
\hline Salbutamol & 134202 & (100) & 89,8 & 9,2 & 1,0 & 0,1 & 0,01 & 6 & 12,3 \\
\hline - kvinner & 71855 & (54) & & & & & & & \\
\hline
\end{tabular}


av de vanedannende enn blant brukerne av de ikke-vanedannende legemidlene. Indikasjon på misbruk støttes også av at brukerne av diazepam, karisoprodol og kodeinkombinasjoner i tillegg til det aktuelle medikamentet, i vesentlig større grad enn brukerne av de tre ikke-vanedannende legemidlene, også får utlevert (andre) benzodiazepiner og opioider. En separat studie med søkelys på karisoprodol, men basert på det samme datamaterialet, fant dessuten at storbrukere av karisoprodol oftere fikk sin forskrivning fra den $1 \%$ av legene som hadde høyest forskrivning av benzodiazepiner og opioider (16). Ved bruk av Lorenz-kurver må vi likevel ta det forbehold at stort forbruk ikke utelukkende behøver å bety legemiddelmisbruk i tradisjonell forstand. Det kan skyldes at noen pasienter er sykere og trenger mer av medikamentet. Dette kan være forklaringen på den høye 1-prosentilverdien for salbutamol i denne studien, og liknende mekanismer kan heller ikke helt utelukkes for vanedannende legemidler.

Vår studie viser stor grad av samvariasjon for det enkelte legemiddel mellom Lorenz $1 \%$-verdien og antall leger som benyttes. Videre viser figur 1 at det også er en positiv samvariasjon mellom antall leger og den utleverte mengden av legemidlet, og også med sambruk av andre kjente misbruksmedikamenter. Denne studien tyder således på at Lorenz $1 \%$-verdien sammen med påvisning av legemiddelshopping og samtidig bruk av andre avhengighetsskapende medisiner, kan hjelpe oss til å peke ut misbruksmedikamenter.

Styrken ved denne studien er at den er basert på data fra et kvalitetssikret register som omfatter alle ekspedisjoner av de undersøkte legemidlene til hele Norges befolkning for det aktuelle kalenderåret. Det er ikke tidligere gjort studier av fenomenet legemiddelshopping på basis av tilsvarende data fra et reseptregister. Svakheten er at vi har et begrenset antall forklaringsvariabler og må basere oss på en antakelse om at det å få forskrevet legemidlet fra flere leger innebærer en aktivt søkende atferd i den hensikt å skaffe seg et legemiddel. Det høye antall leger som blir benyttet av noen få pasienter, taler likevel for at dette ikke bare kan forklares med tilfeldigheter. At legemidlet er utlevert i pasientens navn, er ikke det samme som at pasienten selv har konsumert det - et betydelig videresalg er vist $i$ enkelte studier (5).

Det kan imidlertid være andre grunner til at man får utskrevet medikamenter fra flere leger. Kodeinkombinasjoner spesielt, men også diazepam og karisoprodol, er mye brukt $i$ akuttbehandling og vil derfor bli forskrevet oftere ved legevakt og annen akutt legehjelp der den faste legen ikke er involvert, enn tilsvarende for esomeprazol, metformin og salbutamol. Noen vil hevde at dette vil gi for høye tall for legemiddelshopping, mens andre vil hevde at dette også
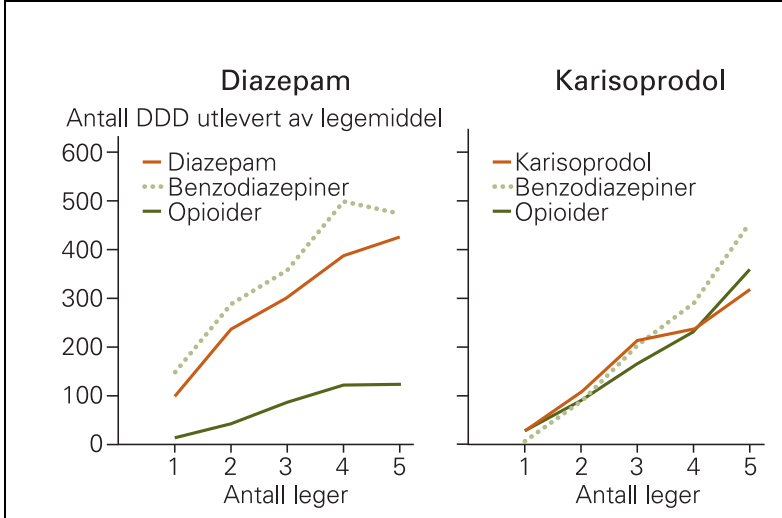

Kodeinkombinasjoner

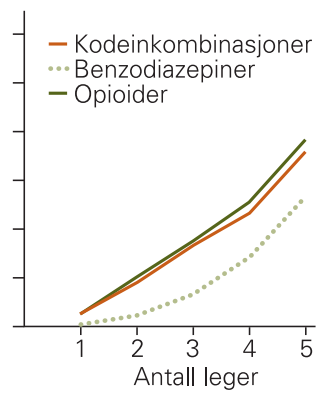

Esomeprazol

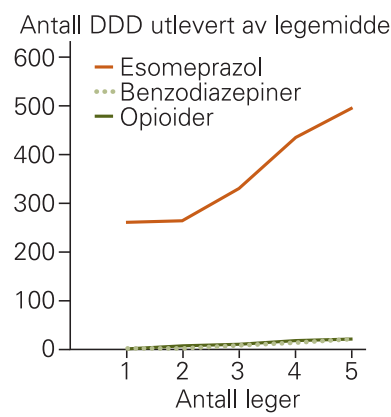

Metformin

Salbutamol

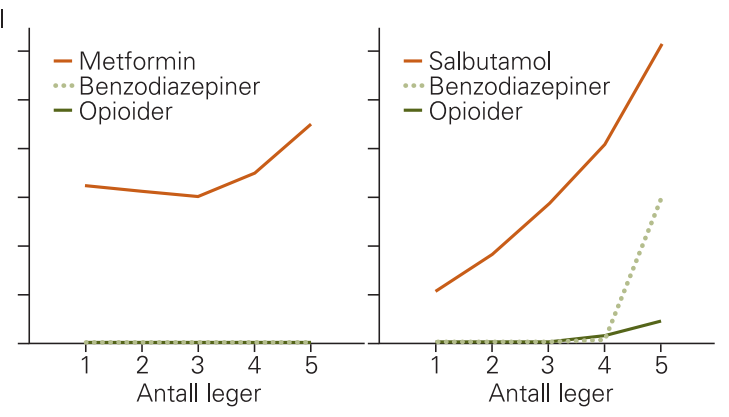

Figur 1 Mengde utlevert av seks ulike legemidler etter antall leger benyttet. De seks diagrammene viser 75-prosentilene (mengde legemiddel utlevert til de $25 \%$ som fikk utlevert mest) for diazepam, karisoprodol, kodeinkombinasjoner, esomeprazol, metformin og salbutamol, samt for gruppen opioider og benzodiazepiner til de samme pasientene. Mengde utlevert legemiddel i løpet av 2004 er angitt i definerte døgndoser av hvert legemiddel

må regnes med til fenomenet. Videre kan pasienter tenkes å ville oppsøke flere leger ved alvorlig sykdom eller på grunn av lange ventetider hos fastlege. Alvorlig syke pasienter vil kunne få forskrevet mer av medisiner mot angst og smerte og slik sett bidra til de høye tallene. At legemidler i utleveringsgruppe $\mathrm{C}$ ofte reitereres, mens dette ikke er mulig for legemidler i gruppene A og $\mathrm{B}$, vil i denne studien kunne gi høyere antall utleveringer av de ikke-vanedannende legemidlene forskrevet fra samme lege, enn for de vanedannende, der pasienten må henvende seg til lege hver gang for å få ny resept. For øvrig kan tett samarbeid og vikariering mellom legene i en gruppepraksis medføre at disse oftere forskriver vanedannende legemidler for hverandre og således bidrar til å øke antall forskrivende leger for samme legemiddel.

Ett av ønskene ved innføringen av fastlegeordningen var å få legemiddelshoppingen under kontroll $(8,9)$. Det finnes ingen studier av legemiddelshoppingfenomenet fra tiden før fastlegeordningens innføring som kan si oss om omfanget har endret seg. Vår studie viser imidlertid at fastlegeordningen ikke har forhindret at legemiddelshopping som fenomen fremdeles eksisterer, men omfanget synes å være begrenset. Når bruk av fem eller flere leger er nesten ti ganger hyppigere for de vanedannende enn for de ikke vanedannende legemidlene, tyder dette på at enkelte pasienter fortsatt bedriver legemiddelshopping. Den store forskjellen mellom de to gruppene av legemidler kan vanskelig forklares med andre forhold enn at bruk uten tilstrekkelig medisinsk indikasjon må spille en stor rolle.

$\mathrm{Vi}$ sammenliknet utleveringsmønsteret for kun seks skjønnsmessig utvalgte legemidler. Det bør utføres en bredere analyse av utleveringsmønsteret for flere legemidler for å få bekreftet denne studiedesignens anvendbarhet og validitet med henblikk på å avdekke omfanget av legemiddelshopping. Gjentatte studier med samme design vil kunne egne seg som måleinstrument for å avdekke hvorvidt omfanget av fenomenet legemiddelshopping endrer seg over tid, og for å se om enkelte legemidler peker seg ut som spesielt attraktive for legemiddelmisbruk. Dette vil i så fall kunne gi verdifull informasjon til helsemyndighetene i overvåkningen av denne siden av legemiddelforbruket $\mathrm{i}$ befolkningen.

Artikkelen er basert på datamaterialet til en oppgave for Master of Public Health av Rolf B. Winther ved Nordiska högskolan för folkhälsovetenskap, Göteborg.

Oppgitte interessekonflikter: Ingen 


\section{Litteratur}

1. Rønning M. Legemiddelforbruket i Norge 2002-2006. Oslo: Nasjonalt folkehelseinstitutt 2007

2. Waal H, Mørland J. Rusmiddelbruk og avhengighetstilstander. I: Trygve Fjeldstad, red. Norsk legemiddelhåndbok. Bergen: Fagbokforlaget, 2007. www.legemiddelhandboka.no/xml/ (13.4.2008).

3. Oliver $P$, Keen J, Rowse $G$ et al. Deaths from drugs of abuse in Sheffield, 1998: the role of prescribed medication. Br J Gen Pract 2001; 51: 394-6.

4. Martyres RF, Clode D, Burns JM. Seeking drugs or seeking help? Escalating «doctor shopping» by young heroin users before fatal overdose. Med J Aust 2004; 180: 211-4.

5. Smith-Solbakken M, Lie T. Piller på avveie. RF1999/097. Stavanger: Rogalandsforskning. 1999.

6. Klienschmidt R, Price J, Caught K. Doctor shopping. Aust Fam Physician 1995; 24: 1037-41.

7. Pradel V, Thirion X, Ronfle E et al. Assessment of doctor-shopping for high dosage buprenorphine maintenance treatment in a French region: development of a new method for prescription database. Pharmacoepidemiol Drug Safe 2004; 13 : 473-81.

8. St.meld. nr. 23 (1996-97). Trygghet og ansvarlighet. Om legetjenesten i kommunene og fastlegeordningen. Oslo: Sosial- og helsedepartementet, 1997

9. Ot.prp. nr. 99 (1998-99). Om lov om endringer i lov av 19. november $1982 \mathrm{nr} .66$ om helsetjenesten i kommunene og i visse andre lover (fastlegeordningen). Oslo: Sosial- og helsedepartementet, 1999.

10. Styringsdata for fastlegeordningen, 3. kvartal 2007. Oslo: Arbeids- og velferdsdirektoratet, oktober 2007. www.nav.no/binary/805364343/file (13.4.2008)

11. Furu K, Strøm H, Rønning M et al. The Norwegian Prescription Database (NorPD): new register for pharmacoepidemiological research covering a whole nation. Pharmacoepidemiol Drug Safe 2005; 14: $\$ 48$

12. Hallas J, Støvring H. Templates for analysis of individual-level prescription data. Basic Clin Pharmacol Toxicol 2006; 98: 260-5.

13. Kamien M. «Doctor shoppers»: at risk by any other name. Med J Aust 2004; 180: 204-5

14. Darke S, Ross J, Teesson M et al. Health service utilization and benzodiazepine use among young heroin users: findings from the Australian Treatment Outcome Study (ATOS). Addiction 2003; 98 : 1129-35.

15. Burns JM, Martyres RF, Clode D et al. Overdose in young people using heroin: associations with mental health, prescription drug use and personal circumstances. Med J Aust 2004; 181 (7 suppl): 25-8.

16. Bramness JG, Furu K, Engeland A et al. Carisoprodol use and abuse in Norway: a pharmacoepidemiological study. Br J Clin Pharmacol 2007; 64: 210-8.

Manuskriptet ble mottatt 13.4. 2008 og godkjent 22. 12. 2008. Medisinsk redaktør Trine B. Haugen. 